February 2005 - NREL/CP-520-37444

\title{
Comparison of Diode Quality Plus Other Factors in Polycrystalline Cells and Modules from Outdoor and Indoor Measurements
}

\author{
J.A. del Cueto and S.R. Rummel
}

Prepared for the $31^{\text {st }}$ IEEE Photovoltaics Specialists Conference and Exhibition Lake Buena Vista, Florida January 3-7, 2005
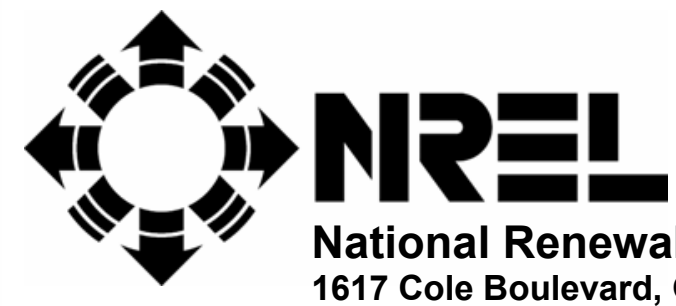

National Renewable Energy Laboratory 1617 Cole Boulevard, Golden, Colorado 80401-3393 303-275-3000 • www.nrel.gov

Operated for the U.S. Department of Energy Office of Energy Efficiency and Renewable Energy by Midwest Research Institute $\bullet$ Battelle 


\section{NOTICE}

The submitted manuscript has been offered by an employee of the Midwest Research Institute (MRI), a contractor of the US Government under Contract No. DE-AC36-99G010337. Accordingly, the US Government and MRI retain a nonexclusive royalty-free license to publish or reproduce the published form of this contribution, or allow others to do so, for US Government purposes.

This report was prepared as an account of work sponsored by an agency of the United States government. Neither the United States government nor any agency thereof, nor any of their employees, makes any warranty, express or implied, or assumes any legal liability or responsibility for the accuracy, completeness, or usefulness of any information, apparatus, product, or process disclosed, or represents that its use would not infringe privately owned rights. Reference herein to any specific commercial product, process, or service by trade name, trademark, manufacturer, or otherwise does not necessarily constitute or imply its endorsement, recommendation, or favoring by the United States government or any agency thereof. The views and opinions of authors expressed herein do not necessarily state or reflect those of the United States government or any agency thereof.

Available electronically at http://www.osti.gov/bridge

Available for a processing fee to U.S. Department of Energy and its contractors, in paper, from:

U.S. Department of Energy

Office of Scientific and Technical Information

P.O. Box 62

Oak Ridge, TN 37831-0062

phone: 865.576 .8401

fax: 865.576.5728

email: mailto:reports@adonis.osti.gov

Available for sale to the public, in paper, from:

U.S. Department of Commerce

National Technical Information Service

5285 Port Royal Road

Springfield, VA 22161

phone: 800.553 .6847

fax: 703.605.6900

email: orders@ntis.fedworld.gov

online ordering: http://www.ntis.gov/ordering.htm 


\title{
COMPARISON OF DIODE QUALITY PLUS OTHER FACTORS IN POLYCRYSTALLINE CELLS AND MODULES FROM OUTDOOR AND INDOOR MEASUREMENTS
}

\author{
J.A. del Cueto, S. R. Rummel, National Renewable Energy Laboratory (NREL), 1617 Cole Blvd., Golden, CO 80401, USA
}

\begin{abstract}
The Outdoor Test Facility (OTF) at NREL is equipped with data acquisition systems that monitor the performance of modules deployed outdoors in real time, including the measurement of current-voltage traces every 15 minutes during all daylight hours. This affords us the ability to analyze performance across many levels of illumination which allows the determination of factors that affect module performance and that serve as indicators of module quality, including average diode quality factors, series resistances values, and reverse-saturation currents of the cells. This study focuses on several polycrystalline thinfilm modules, including cadmium telluride. CIS, and polycrystalline silicon. We present these parameters, acquired from outdoor measurements, and compare the results with measurements obtained from more canonical methods.
\end{abstract}

\section{INTRODUCTION}

Current-voltage (I-V) measurements are routinely used to derive materials' properties in photovoltaic (PV) cells [1]. Routine measurements performed on cells like dark and light I-V measurements and analyses yield information on semiconductor and contact material quality, including diode quality factors and series resistance, allowing correlation with any shortcomings in performance. Albeit, the size and distribution of series resistance and currents present in modules can skew the analysis and accurate determination of this information garnered from these measurements [2].

Oftentimes, we tend to avoid executing the same analyses on modules that are performed on cells, perhaps because of the perceived difficulty in interpreting the results for modules. Typically, one can only obtain average cell parameter values over the whole module without doing destructive testing or other special techniques that can isolate individual cells [3]. However, this limitation should not preclude our attempting to analyze valuable data, especially when it is already amply present and can provide useful information. Even the accurate determination of series resistance is oftentimes lacking, instead while using the slope of the I-V trace at the open-circuit condition measured at 1-sun intensity. In this paper, the data taken from many I-V traces recorded outdoors are analyzed to obtain series resistance values, diode quality factors and reverse saturation currents. Those results are compared with measurements for the same modules taken indoors using a solar simulator to the trace dark and light I-V characteristics.

\section{ANALYTIC CONSIDERATIONS}

A canonical method used to calculate the series resistance $R_{s}$, the diode quality factor $A$, and the reverse saturation current density $\left(\mathrm{J}_{0}\right)$ in PV devices is derived from the I-V curves. This method relies on the ideal singlediode model with lumped series and shunt resistance terms, as detailed in the literature [1]. This model is formulated by Eqn. 1, reproduced below, where $\mathrm{J}$ is the total current density, $J_{0}$ is the saturation current density, $V$ is the voltage measured at the external contacts, $R_{s}$ and $G$ are the lumped parasitic series resistance and shunt conductance terms, respectively, $q$ is the electronic charge, $A$ is the diode quality factor, $\mathrm{k}$ is Boltzman's constant, $\mathrm{T}$ is the absolute temperature in ${ }^{\circ} \mathrm{K}$, and $\mathrm{J}_{\mathrm{L}}$ is the photogenerated current, which may be replaced with the shortcircuit current density $\mathrm{J}_{\mathrm{SC}}$, if shunting is negligible.

$$
J=J_{0} \cdot\left[e^{q \cdot\left(V-R_{S} J\right) / A k T}-1\right]+G V-J_{L}
$$

The validity of this model is dependent on the applicability of the principle of superposition, whereby the effect of illumination is simply to displace the current by an amount equal to $J_{L}$ everywhere along the I-V curve and whereby all other terms in Eqn. 1 retain their unilluminated and/or unbiased values. Reference [1] and many others generally execute the analysis using either the dark I-V data-special case where $\mathrm{J}_{\mathrm{L}}$ is zero-and/or light I-V data at one-sun illumination. However, there really is nothing sacrosanct about performing the analysis at just these two illuminations, especially since some of the parameters entering into Eqn. 1 can be either bias or light dependent. An equally viable or perhaps even better, albeit more protracted, strategy would be to apply similar analysis but under varying illumination levels. Towards this end, the $R_{s}, A$ and $J_{0}$ are derived using equations 2 and 3 , as previously reported [4]. The symbols for terms used in equations 2 and 3 are the same as those in Eqn. 1, plus $R_{o c}$ is the slope of the I-V curve at the open-circuit condition. The analysis requires performing a sufficient number of I-V traces to obtain $V_{o c}$ and $R_{o c}$ at a range of illuminations, resulting in various $\mathrm{J}_{\mathrm{L}}$ all referenced to the same temperature. In practice, this measurement strategy and analysis are time consuming and seldom executed. However, with the benefits of automatic data acquisition, plus modules and time, this is no longer an impediment.

$$
R_{O C}=R_{S}+\frac{A k T}{q} \cdot \frac{1}{\left(J_{L}+J_{0}-G V_{O C}\right)}
$$




$$
V_{O C}=\frac{A k T}{q} \cdot \operatorname{Ln}\left(1+J_{L} / J_{0}\right)
$$

Equations 2 and 3 are otherwise very similar to the formulae used in single-trace analysis. However, in Eqn. 2 on the left-hand side, $R_{o c}$ is the slope of the curve $(d V / d J)$ at open circuit, and on the right-hand side the denominator term is $J_{0}+J_{L}-G V_{o c}$ instead of $J+J_{L}$. In Eqn. $3, V_{o c}$ and $J_{L}$ have now replaced $V$ and $J$. However, for a module, the term for the diode factor A present in equations 2 and 3 is now replaced by the sum of all of the diode quality factors for the cells connected in series in the module, and the and $R_{s}$ and $G$ are now the sum of lumped distributed series and shunt conductance terms. From Eqn. 2, at high enough illumination, one can usually neglect the terms $\mathrm{J}_{0}$ and $\mathrm{GV}_{\mathrm{oc}}$ in the denominator. Equations 2 and 3 are hereafter referred to as the alternate method of derivation.

\section{EXPERIMENTAL METHOD}

Outdoor performance data for three distinct PV technologies are scrutinized: 3 cadmium telluride (CdTe) modules (A, B, C); 2 copper indium diselenide (CIS) modules $(\mathrm{A}, \mathrm{B})$ and 2 polycrystalline silicon ( $\mathrm{pc}-\mathrm{Si})$ modules $(\mathrm{A}, \mathrm{B})$. Their I-V characteristics are analyzed: the behavior of the open-circuit voltage $\left(V_{o c}\right)$, short-circuit current $\left(\mathrm{I}_{\mathrm{sc}}\right)$, fill factor (FF), plus the slope of the I-V curves at the open-circuit condition $\left(R_{o c}\right)$ and their respective temperature coefficients are derived from outdoor measurements, for irradiance levels ranging from low $\left(50 \mathrm{~W} / \mathrm{m}^{2}\right)$ to high $(1200$ $\mathrm{W} / \mathrm{m}^{2}$ ), with module temperatures ranging from $20^{\circ}$ to $65^{\circ} \mathrm{C}$. Irradiance data were measured with a broadband pyranometer mounted in the same plan-of-array as the modules; the temperatures represent back-of-module measurements; both are sampled simultaneously with the I-V traces. The featured modules are deployed facing south at fixed latitude tilt on the Performance and Energy Ratings Testbed (PERT) on the roof of the OTF at NREL.

The noted I-V parameters were evaluated at $25^{\circ} \mathrm{C}$ in discreet intervals of irradiance going from low $\left(50 \mathrm{~W} / \mathrm{m}^{2}\right)$ to high $\left(1200 \mathrm{~W} / \mathrm{m}^{2}\right)$ values. This was accomplished by leastsquares fitting the individual parameters $\left(V_{o c}, I_{s c}, R_{o c}\right.$, etc.) to a linear function of module of temperature in each bin followed by evaluation at $25^{\circ} \mathrm{C}$. The data were then normalized to unit-area cell values: for $V_{\text {oc }}$ by dividing by the number of cells in series; for $\mathrm{J}_{\mathrm{sc}}$ by dividing by the area of the unit cell in each module, taken as the aperture area divided by the number of series-connected cells. The parameter evaluations at $25^{\circ} \mathrm{C}$ were subsequently fit according to equations 2 and 3 , in order to obtain values for $R_{s}, A$ and $\mathrm{J}_{0}$. The modules were removed from the PERT recently, to measure dark and light I-V performed on the Large-Area Continuous Solar Simulator (LACSS) at standard test conditions (STC) followed by the standard analysis applied to obtain the same parameters. For CdTe modules, there are two tests performed for each dark and light I-V on the LACSS: one in the so-called 'storage state' and a second labeled the 'light-stabilized state.' This additional testing for $\mathrm{CdTe}$ is performed to mitigate transient effects, whereby the module is exposed to $10-\mathrm{min}$ or more continuous illumination at open circuit.

\section{RESULTS}

Figure 1 is a graph depicting the unit-area cell, normalized slope at open-circuit conditions $\left(R_{o c}\right)$, plotted against the reciprocal of $\mathrm{J}_{\mathrm{sc}}$ for various illuminations, evaluated at $25^{\circ} \mathrm{C}$ for the seven modules featured. This data represents a severe condensation of outdoor data, with each point representing at least several hundred individual statistics, for irradiance between $150 \mathrm{~W} / \mathrm{m}^{2}$ and $1150 \mathrm{~W} / \mathrm{m}^{2}$, where high-illumination data occur towards the origin. The data for the two pc-Si modules appear near the bottom of the figure almost coincident on top of one another. The CIS A and B modules occupy the next niche of resistance values higher up, and then the CdTe modules appear at the largest resistance values. Both the CIS and pc-Si data appear to behave fairly linearly within this range of illumination, as well as that for the CdTe A module. Within a slightly more restricted linear range, the terms $\mathrm{J}_{0}$ and $\mathrm{GV}_{\mathrm{oc}}$ in the denominator of Eqn. 2 may be neglected. Hence, from the intercept of the data with the abscissa one obtains the series resistance as per Eqn. 2. From the slope, the values of $A$ are derived, as well.

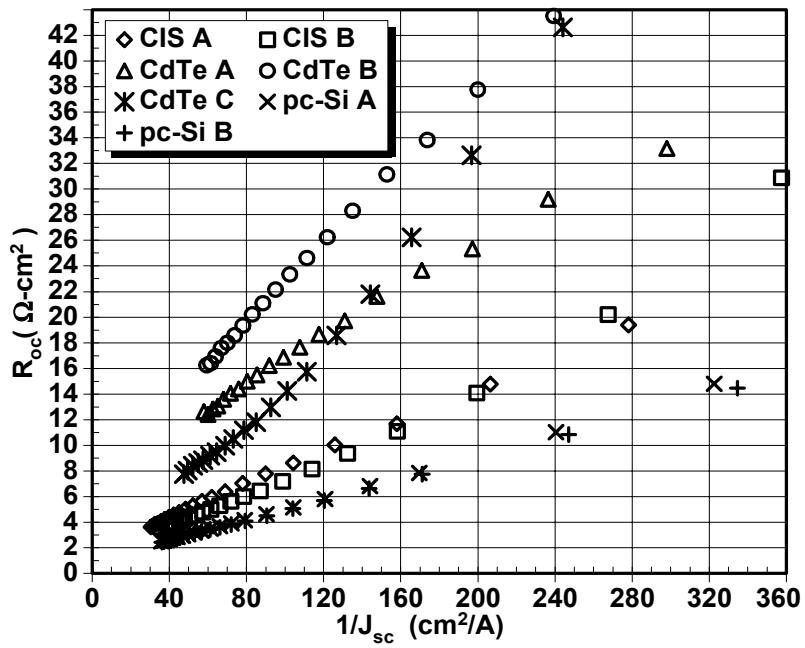

Fig. 1. Unit-area cell $R_{o c}$ plotted against the reciprocal of $\mathrm{J}_{\mathrm{sc}}$, from variable illumination outdoor data reduced to $25^{\circ} \mathrm{C}$ temperature for seven polycrystalline modules.

Figure 2 portrays $\mathrm{J}_{\mathrm{sc}}$ on a semilog abscissa against $V_{o c}$ along the ordinate axis for the same seven modules, from the sampled outdoor data taken between $50 \mathrm{~W} / \mathrm{m}^{2}$ and $1150 \mathrm{~W} / \mathrm{m}^{2}$ irradiance, reduced to $25^{\circ} \mathrm{C}$ temperature. The range of $\mathrm{J}_{\mathrm{sc}}$ values covered in this graph is not as great as one usually obtains for $\mathrm{J}$ in single traces, but note the rather straight linear behavior with the log of $\mathrm{J}_{\mathrm{sc}}$, except for the lowest illuminations. The data for the pc-Si modules appear largely near middle within the $0.48-0.6$ voltage range. The CdTe A and B modules' data appear at the extreme right, and the CIS A module is at extreme left. The CIS B data is between the pc-Si and CdTe modules' data, and $\mathrm{CdTe} C$ data run across the entire voltage range. Any non-linear behavior between the log of $\mathrm{J}_{\mathrm{sc}}$ and $V_{o c}$ are likely to result from sizable shunt conductance. From the characteristic slope of $V_{o c}$ as a function of log of $\mathrm{J}_{\mathrm{sc}}$, one obtains the diode factor $\mathrm{A}$ and $\mathrm{J}_{0}$. 


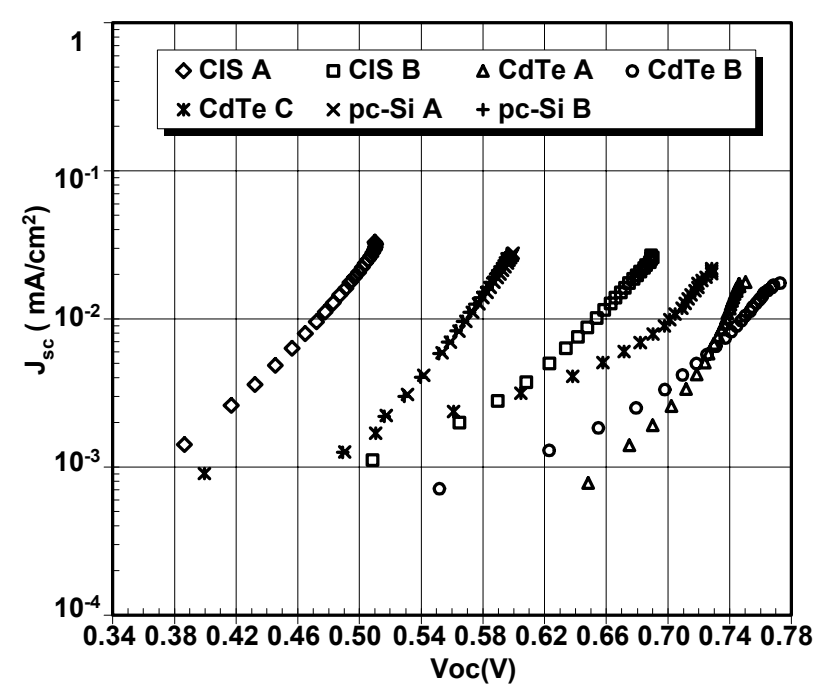

Fig. 2. Unit-area cell $J_{s c}$ plotted along the semilog abscissa, against cell $V_{\text {oc }}$ along the ordinate from variable illumination outdoor data reduced to $25^{\circ} \mathrm{C}$ temperature.

Figure 3 depicts the slopes $\mathrm{dV} / \mathrm{dJ}$ of the light I-V data normalized to unit cell area measured on the LACSS at STC plotted against $1 /\left(\mathrm{J}+\mathrm{J}_{\mathrm{L}}\right)$ for six polycrystalline modules, shown in forward bias typically greater than the optimum operating point voltage. The data for the pc-Si B module has been omitted for clarity because it is so similar to that of pc-Si A module. On Fig. 4, the slopes $\mathrm{dV} / \mathrm{dJ}$ of the dark I-V data, normalized to unit-area values and measured on the LACSS at $25^{\circ} \mathrm{C}$, are plotted against the $1 / \mathrm{J}$ for the same six modules. These data are measured out to voltages corresponding to $120 \%-125 \%$ of the respective $V_{o c}$ for each module, albeit the currents at these voltages aren't always as large as the 1-sun $I_{\mathrm{sc}}$ values. The abscissa in Fig. 4 has been extended in order to depict the data for all six modules, including $\mathrm{CdTe}$ data that are substantially larger than those in Fig. 1.

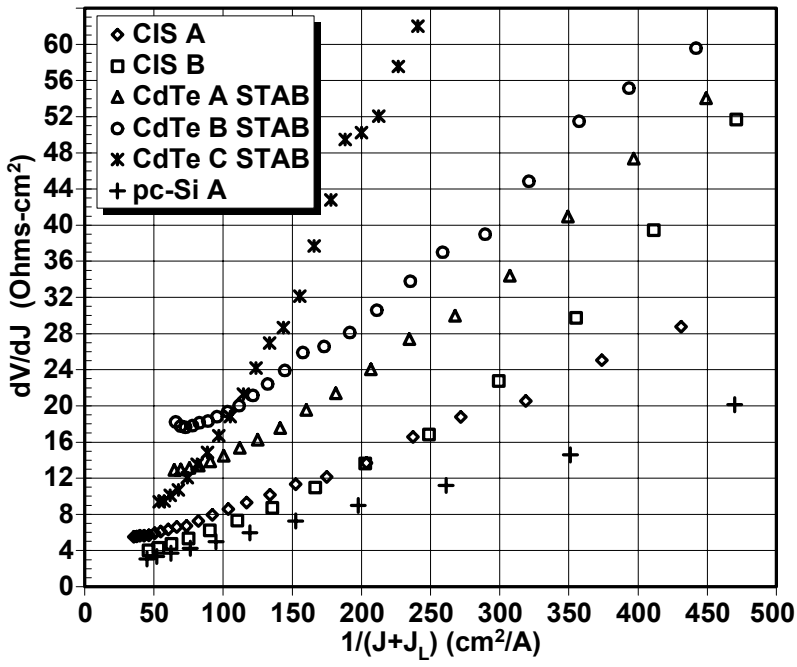

Fig. 3. Normalized slopes $\mathrm{dV} / \mathrm{dJ}$ of light I-V traces plotted against $1 /\left(\mathrm{J}+\mathrm{J}_{\mathrm{L}}\right)$, as measured on LACSS at STC for six polycrystalline modules.

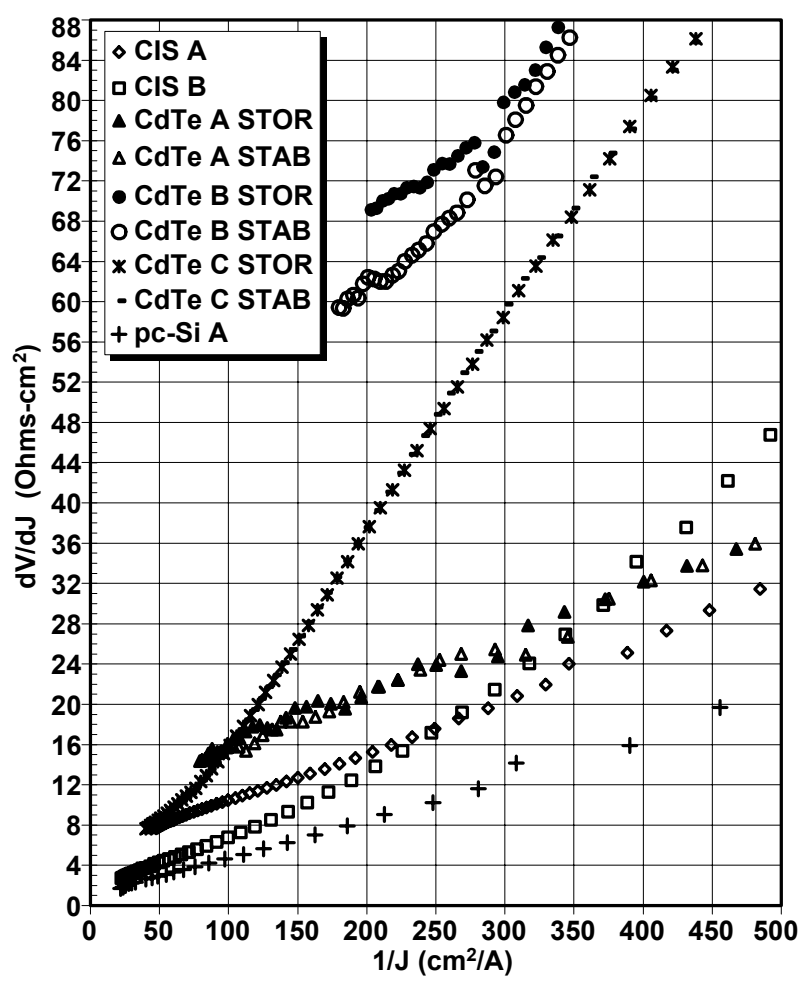

Fig. 4. Normalized slopes $\mathrm{dV} / \mathrm{dJ}$ of dark I-V traces plotted against $1 / \mathrm{J}$, measured on LACSS at $25^{\circ} \mathrm{C}$ for six polycrystalline modules, also showing storage (STOR) and lightstabilized (STAB) data for the CdTe modules.

Two different data sets, storage (STOR) and stabilized (STAB), are depicted in Fig. 4 for each CdTe module, respectively, representing measurements taken immediately after storage in low-light level conditions and after light stabilization under the LACSS. For one of the CdTe modules $(B)$ there are significant differences between the 'storage' and 'stabilized' data. However, for CdTe modules $A$ and $C$, these differences are small. For the CdTe modules, only the light-stabilized data are portrayed in Fig. 3. Note that for CdTe modules, there are substantial differences between the slopes obtained from the dark and light $\mathrm{I}-\mathrm{V}$ data sets. Generally, the slopes are shifted to lower values for the light I-V data, and for the CdTe B module, there is a large shift in the data toward lower values present. For the pc-Si A and both CIS modules, however, the differences between dark and light data are slight.

\section{ANALYSIS}

From the data in Figures 1-4, and from the light and dark I-V traces taken on the LACSS, values for series resistance $R_{s}, A$ and $J_{0}$ were derived. The standard analysis using single dark and light I-V traces follows that of reference [1] to obtain the parameters, with dual values of $A$ realized. The outdoor data are analyzed by the alternate method formulated by Equations 2 and 3, and also results in dual values for $A$. These data are organized in Tables 1 and 2 , respectively, for the standard and alternate analyses. In both tables, the first left columns list the modules, and the second rows list the method used for derivation. 
Table 1. Parameters obtained from single dark and light I-V Traces using the standard analysis.

\begin{tabular}{|c|c|c|c|c|c|c|c|c|}
\hline & \multicolumn{4}{|c|}{ Dark I-V } & \multicolumn{4}{c|}{ Light I-V } \\
\hline & \multicolumn{2}{|c|}{$\mathbf{d V / d J - 1 / J}$} & \multicolumn{2}{c|}{ Log(J)-V } & \multicolumn{2}{|c|}{$\mathbf{d V / d J - 1 / ( J + J _ { \mathbf { L } }}$} & \multicolumn{2}{c|}{$\mathbf{L o g}\left(\mathbf{J}+\mathbf{J}_{\mathbf{L}}\right)-\mathbf{V}$} \\
\cline { 2 - 10 } & $\begin{array}{c}\mathbf{R}_{\mathbf{s}} \\
\Omega-\mathbf{c m}^{2}\end{array}$ & $\mathbf{A}$ & $\begin{array}{c}\mathbf{J}_{0} \\
\mathrm{~A} / \mathrm{cm}^{2}\end{array}$ & $\mathbf{A}$ & $\begin{array}{c}\mathbf{R}_{\mathbf{s}} \\
\Omega-\mathrm{cm}^{2}\end{array}$ & $\mathbf{A}$ & $\begin{array}{c}\mathbf{J}_{\mathbf{0}} \\
\mathrm{A} / \mathrm{cm}^{2}\end{array}$ & $\mathbf{A}$ \\
\hline CIS A & 5.6 & 1.9 & $5.3 \mathrm{E}-07$ & 1.9 & 3.2 & 2.1 & $2.1 \mathrm{E}-06$ & 2.1 \\
\hline CIS B & 1.5 & 2.2 & $8.1 \mathrm{E}-08$ & 2.2 & 1.2 & 2.2 & $2.0 \mathrm{E}-07$ & 2.3 \\
\hline CdTe A & 9.9 & 2.2 & $2.9 \mathrm{E}-09$ & 2.2 & 6.2 & 3.4 & $2.2 \mathrm{E}-06$ & 3.4 \\
\hline CdTe B & 44.7 & 4.4 & $1.1 \mathrm{E}-05$ & 4.3 & 8.2 & 4.2 & $2.0 \mathrm{E}-05$ & 4.3 \\
\hline CdTe C & 2.9 & 4.6 & $2.6 \mathrm{E}-05$ & 4.9 & -2.2 & 7.7 & $5.0 \mathrm{E}-04$ & 8.1 \\
\hline pc-Si A & 1.0 & 1.5 & $6.0 \mathrm{E}-09$ & 1.6 & 1.2 & 1.5 & $1.2 \mathrm{E}-08$ & 1.6 \\
\hline
\end{tabular}

Table 1 is split into two sections, shown at left and right, respectively, representing values derived from dark $\mathrm{I}-\mathrm{V}$ data, and from the light I-V data. The second and sixth data columns list the $R_{s}$ obtained from the dark and light $\mathrm{I}-\mathrm{V}$ traces, respectively. Columns three and five list the $\mathrm{A}$ factors derived, respectively, from the intercepts of the $\mathrm{dV} / \mathrm{dJ}$ vs. $1 / \mathrm{J}$ and from the slope of $V$ versus the $\log (\mathrm{J})$, for the dark I-V traces; columns seven and nine list the $A$ values obtained similarly respectively for light I-V data. Table 1 shows that for the thin-film modules at least, the $R_{s}$ obtained from light I-V data are lower than those obtained from dark I-V traces. Note for the CdTe $\mathrm{C}$ module, the series resistance derived from light $\mathrm{I}-\mathrm{V}$ is negative and meaningless. Yet, that is consistent with expectation from crudely drawing a straight-line fit to the data for this module shown in Fig. 3, suggesting extreme sensitivity to fitting range. Also note the drastic change in $R_{s}$ for CdTe $B$ that appears between dark and light measurements.

Table 2. Parameters derived from outdoor data I-V data across varying illumination, using the alternate method.

\begin{tabular}{|c|c|c|c|c|}
\hline \multirow[t]{2}{*}{ Module } & $\begin{array}{c}\mathbf{R}_{\mathbf{s}} \\
\Omega-c m^{2}\end{array}$ & A & $\begin{array}{c}J_{0} \\
A / c^{2} \\
\end{array}$ & A \\
\hline & \multicolumn{2}{|c|}{$R_{o c}-1 / J_{s c}$} & \multicolumn{2}{|c|}{$V_{o c}-\log \left(J_{s c}\right)$} \\
\hline $\mathrm{CIS} \mathrm{A}$ & 1.8 & 2.5 & $5.2 \mathrm{E}-09$ & 1.3 \\
\hline CIS B & 1.3 & 2.3 & $4.7 \mathrm{E}-10$ & 1.5 \\
\hline CdTe A & 6.8 & 3.9 & $1.2 \mathrm{E}-20$ & 0.7 \\
\hline CdTe B & 7.1 & 6.1 & $3.4 \mathrm{E}-11$ & 1.5 \\
\hline CdTe C & 2.7 & 4.1 & 4.2E-11 & 1.4 \\
\hline pc-Si A & 1.1 & 1.5 & $3.9 \mathrm{E}-11$ & 1.1 \\
\hline pc-Si B & 1.0 & 1.5 & $1.8 \mathrm{E}-11$ & 1.1 \\
\hline
\end{tabular}

Table 2 summarizes the values for the same parameters obtained via alternate analysis. The second column lists the $R_{s}$ values obtained from the intercept of the characteristics of the slopes of $R_{\text {oc }}$ against $1 / J_{\text {sc }}$. Columns three and five list the A factors derived, respectively, from the intercepts of the $R_{\mathrm{oc}}$ versus $1 / \mathrm{J}_{\mathrm{sc}}$ and from the slope of $V_{\text {oc }}$ versus the log of $J_{\text {sc }}$. Values for $J_{0}$ are similarly drawn from the application of Eqn. 3. Comparing $A$ values derived by the $R_{o c}-1 / J_{s c}$ and $V_{o c}-\log \left(J_{s c}\right)$ methods listed in Table 2, the parameters derived by the latter method generally result in lower values than those achieved by the former. With the exception of the CdTe A module, all of the $A$ values attained with the latter method appear quite reasonable and less than or equal to 1.5. The values for $J_{0}$ calculated appear reasonable but possibly a little low. For the CdTe A module, both the derived $A$ and $\mathrm{J}_{0}$ calculated, respectively, as 0.7 and $\sim 1{ }^{*} 10^{20} \mathrm{~A} / \mathrm{cm}^{2}$ are almost certainly artificially low. It is noted that these data were calcu- lated from those depicted in Fig. 2, for $\mathrm{J}_{\mathrm{sc}}$ equal to or larger than $\sim 0.0065 \mathrm{~A} / \mathrm{cm}^{2}$. Using the $R_{o c}-1 / J_{s c}$ method, the parameters were derived for values where the data portrayed in Fig. 1 exhibit linear behavior, generally, for values of $1 / \mathrm{J}_{\mathrm{sc}}$ equal to or less than $\sim 180 \mathrm{~cm}^{2} / \mathrm{A}$.

\section{DISCUSSION AND CONCLUSIONS}

As pointed out [2], the A factors derived for cells or modules with non-negligible series resistance will appear larger than those of the actual cells, due to the generation of a non-uniform voltage distribution across the cells. This probably cannot be factored using the standard analysis. Comparing the A values obtained from the standard versus the alternate methods, it is noted that using the alternate method results in lower values of $A$, by either way: $R_{o c}-1 / J_{s c}$ or $V_{o c}-\log \left(J_{s c}\right)$. Also, the $R_{o c}-1 / J_{s c}$ method makes use of the slope $R_{o c}$ at a multiple number of traces, all at the open-circuit conditions, where the current vanishes and therefore any non-uniform voltages across the cells in the module are likely to be minimized. With the standard method, the resulting values of the series resistance are subsequently used to correct for the voltage across the junction $\left(V-R_{S} J\right)$ to derive both $A$ and $J_{0}$, from single traces. As noted in Figs. 3 and 4 , and to a lesser degree in Fig. 1, oftentimes it is a judgement call as to what the proper linear range to fit the data might be. If there is sizable error in the derived series resistance, this is likely to propagate into and confound the calculation. For parameters derived from $\mathrm{V}_{\mathrm{oc}}-\log \left(\mathrm{J}_{\mathrm{sc}}\right)$, one does not need to correct the data for series resistance, and nonuniform voltage distribution is likely to be less of a problem, but, one does need to ensure that the fitting range isn't befuddled with the effects of shunt conductance.

\section{ACKNOWLEDGEMENTS}

The authors would like to thank Alan Anderberg of the Cell and Module Measurements Team at NREL for assisting with the LACSS measurements at STC. This work was supported by the U.S. Department of Energy under Contract No. DE-AC36-99G010337.

\section{REFERENCES}

[1] S.S. Hegedus, W. N. Shafarman, "Thin-Film Solar Cells: Device Measurements and Analysis," Prog. in PV: Res \& Appl. 12, 2004, pp. 155-176.

[2] I.L. Eisgruber, Ph.D. Dissertation "Role of Nonuniformity in Thin-Film Polycrystalline Module Characterization," Colorado State Univ., Fort Collins, CO, 1996, pp. 44-57.

[3] T.J. McMahon, T. Basso, S.R. Rummel, "Cell Shunt Resistance and Photovoltaic Module Performance," Proc. $25^{\text {th }}$ IEEE PVSC, 1996, p.1291.

[4] J.A. del Cueto, "Method for Analyzing Series Resistance and Diode Quality Factors from Field Data Part II: Applications to Crystalline Silicon," Sol. Ener. Mats. \& Sol. Cells, 59, 1999, pp. 393-405. 


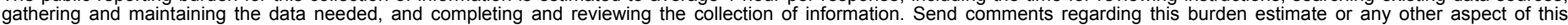

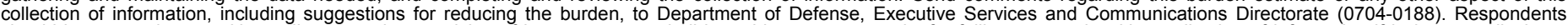

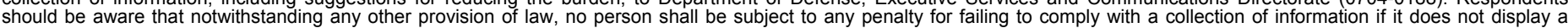

should be aware that notwithstanding

PLEASE DO NOT RETURN YOUR FORM TO THE ABOVE ORGANIZATION.

\begin{tabular}{l|l|l}
\hline 1. $\begin{array}{l}\text { REPORT DATE }(D D-M M-Y Y Y Y) \\
\text { February } 2005\end{array}$ & 2. $\begin{array}{l}\text { REPORT TYPE } \\
\text { Conference Paper }\end{array}$ & $\begin{array}{l}\text { DATES COVERED (From - To) } \\
3-7 \text { January 2005 }\end{array}$ \\
\hline
\end{tabular}

4. TITLE AND SUBTITLE

Comparison of Diode Quality Plus other Factors in Polycrystalline

Cells and Modules from Outdoor and Indoor Measurements 5a. CONTRACT NUMBER

DE-AC36-99-GO10337

5b. GRANT NUMBER

5c. PROGRAM ELEMENT NUMBER

5d. PROJECT NUMBER

NREL/CP-520-37444

5e. TASK NUMBER

PVB57102

5f. WORK UNIT NUMBER
7. PERFORMING ORGANIZATION NAME(S) AND ADDRESS(ES)

National Renewable Energy Laboratory

1617 Cole Blvd.

Golden, CO 80401-3393

9. SPONSORING/MONITORING AGENCY NAME(S) AND ADDRESS(ES)
8. PERFORMING ORGANIZATION REPORT NUMBER

NREL/CP-520-37444
10. SPONSOR/MONITOR'S ACRONYM(S) NREL

11. SPONSORING/MONITORING AGENCY REPORT NUMBER

12. DISTRIBUTION AVAILABILITY STATEMENT

National Technical Information Service

U.S. Department of Commerce

5285 Port Royal Road

Springfield, VA 22161

13. SUPPLEMENTARY NOTES

14. ABSTRACT (Maximum 200 Words)

The Outdoor Test Facility (OTF) at NREL is equipped with data acquisition systems that monitor the performance of modules deployed outdoors in real time, including the measurement of current-voltage traces every 15 minutes during all daylight hours. This affords us the ability to analyze performance across many levels of illumination which allows the determination of factors that affect module performance and that serve as indicators of module quality, including average diode quality factors, series resistances values, and reverse-saturation currents of the cells. This study focuses on several polycrystalline thin-film modules, including cadmium telluride. CIS, and polycrystalline silicon. We present these parameters, acquired from outdoor measurements, and compare the results with measurements obtained from more canonical methods.

15. SUBJECT TERMS

PV; diode quality; module; polycrystalline cells; current-voltage traces; series resistances values; reverse-saturation currents; thin-films; cadmium telluride;

\begin{tabular}{|l|l|l|l|l|}
\hline \multicolumn{3}{|l|}{ 16. SECURITY CLASSIFICATION OF: } & $\begin{array}{c}\text { 17. } \text { LIMITATION } \\
\text { OF ABSTRACT }\end{array}$ & $\begin{array}{c}\text { 18. NUMBER } \\
\text { OF PAGES }\end{array}$ \\
\hline $\begin{array}{l}\text { a. REPORT } \\
\text { Unclassified }\end{array}$ & $\begin{array}{c}\text { b. ABSTRACT } \\
\text { Unclassified }\end{array}$ & $\begin{array}{c}\text { c. THIS PAGE } \\
\text { Unclassified }\end{array}$ & $\begin{array}{c}\text { UL } \\
\end{array}$ &
\end{tabular}

19a. NAME OF RESPONSIBLE PERSON

19b. TELEPHONE NUMBER (Include area code) 